PART TWO

THE STATE 


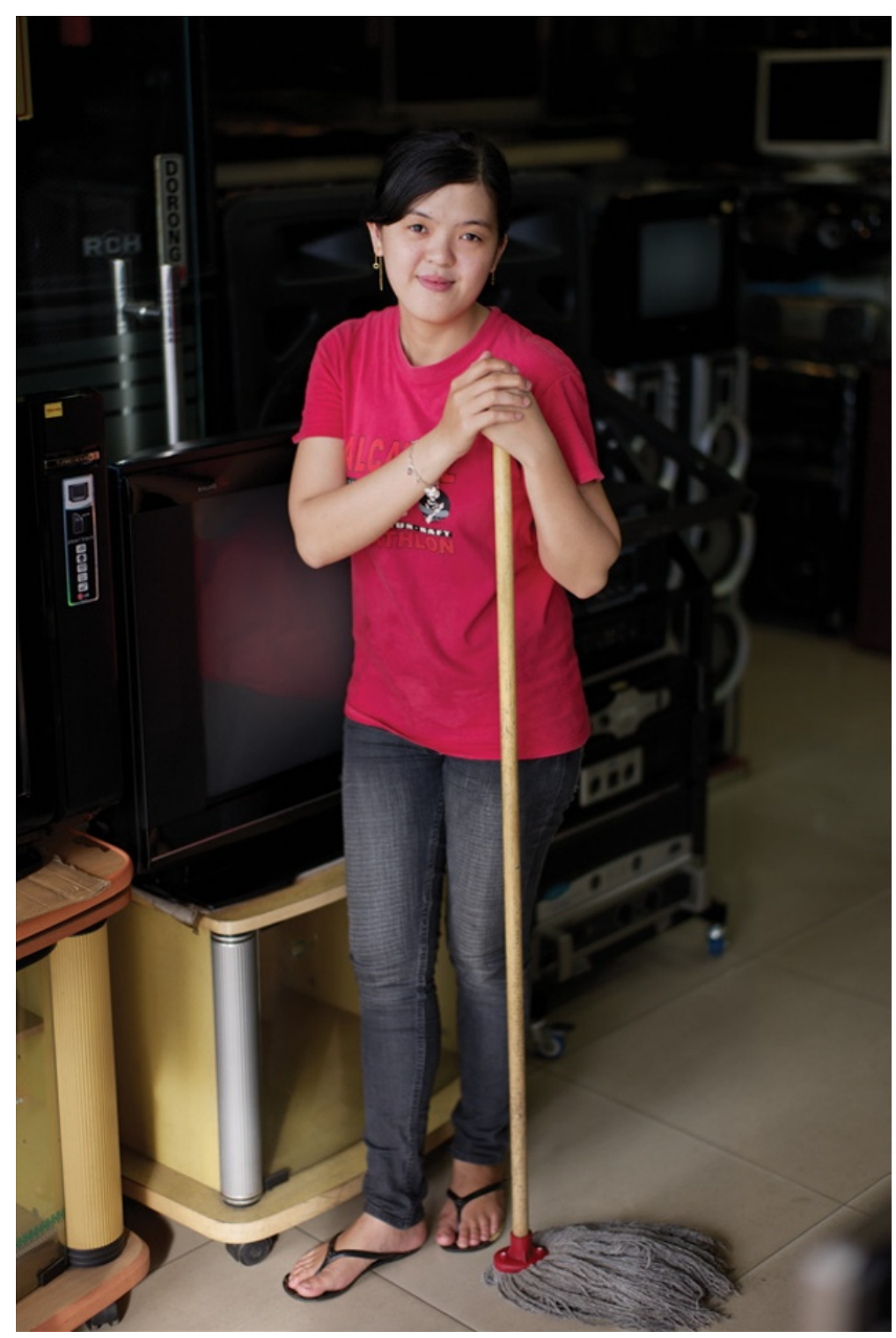

Fig. 5. PONTIANAK: A young woman working in an electronics shop is eager to pose for the camera. Too late, she is chagrined to realize that her mop will undermine the sophisticated air she hoped to project.

June 2010: photo by S. Chris Brown 


\title{
ETHNICITY AND YOUNG PEOPLE'S WORK ASPIRATIONS IN PONTIANAK
}

\author{
Wenty Marina Minza
}

One morning one of my research assistants in Pontianak showed me the morning paper. 'Look', she said in an anxious voice, pointing to the headline, 'the governor has just announced the heads of the provincial offices... all the second echelon people.' I was puzzled; why was this so important? She patiently explained it to me. First, several posts in the list were considered lucrative. All civil servants receive money on top of their salary. It is usually known as 'side money' (uang sampingan), and departments that pay a lot are called 'wet' (basah). The offices for the regional civil-service bureau, public works, education and health are 'wet'. Side money can exceed the salary. Second, these appointments were ethnic. Resting her finger on the name of the new head of the West Kalimantan Regional Civil Service Bureau (Badan Kepegawaian Daerah Kalimantan Barat, responsible for recruitment), she added: 'See, it's a Dayak! Now that the governor is a Dayak, all of the important posts are held by the Dayak....Soon all the provincial civil servants will be Dayak.' ${ }^{2}$ Of course that was just an assumption and perhaps a bit of an exaggeration, but the feeling that this ethnic map of the bureaucracy would affect my assistant's future turned out to be shared by many other young people in this town. The commotion led the governor to state in the local press that he had tried to balance the composition of his cabinet and that ethnicity did not matter in the recruitment process. ${ }^{3}$ My Malay assistant did not believe it. To her it was obvious that more Dayak had been appointed than before.

My assistant, Lia, was a 24-year-old young Malay woman. That day she was wearing skinny jeans and a floral printed blouse. I noticed she had swapped her plain black-framed glasses for matching red ones. Attention to style is typical of young women in Pontianak. Lia had graduated in law

1 'Tengok Kak, baru jak gubernur ngumumkan kepala dinas propinsi, semue eselon dua.' Second echelon is the appropriate civil-service rank for new heads of provincial offices.

2 'Hah, Dayak agek! Sebab gubernur Dayak, semue posisi penting diambik same die (Dayak). Nantek pegawai propinsi pasti Dayak gak semue.'

3 Berkat, 'Gubernur: tidak ada balas dendam,' 15 January 2008. 
from the local state university two years earlier, but had not managed to find 'decent' work. Her idea of decent work was to be a civil servant, a pegawai negeri sipil, or PNS. She had been applying desperately ever since she graduated - seven times to various regional and national offices, all without success. Where I come from in Java, a PNS job is not as major an aspiration among young people. I was surprised by her fixation on getting a PNS job. It made me wonder how typical Lia's obsession was among educated young people in Pontianak.

Pontianak is the provincial capital of West Kalimantan, located on one of the 'outer islands' of Indonesia. It has grown remarkably in recent years. In between the two-storey shop-houses known as ruko (short for rumah toko) and the spacious coffee shops (warung kopi) there are now entertainment facilities such as internet cafés, karaoke bars and billiard rooms. The trained eye - all Indonesians have them - will soon notice the Chinese faces on Pontianak's streets. Wherever you turn, you will see ethnic Chinese - walking along the streets, working in the ruko, selling as street vendors or simply relaxing at coffee shops. But this public scene contrasts with what I see in state offices, schools or health facilities. Ethnic Chinese are almost nowhere in sight. That is when I realized that space in Pontianak is ethnically segregated.

I was then introduced to a 25-year-old Chinese woman, Carla, a parttime clerk at a small Chinese-owned transportation company who was still trying to obtain her university diploma. When I met her at the office she was wearing a simple tight skirt, complemented by a white shirt. She told me that when hanging out in cafés or at the mall, she dresses in short pants and tank tops, with high heels - exactly what my Malay informants call the 'Chinese style' (model cine). When she finishes her study she dreams of moving up in a big, private company. With the money she earns, she hopes to travel the world, to Europe and Japan.

None of the Chinese I spoke with shared Lia's PNS aspiration. Like Lia, they wanted financial independence, but they also wanted selfdevelopment. Eny (19), a Chinese woman from Sekadau in the interior currently working with a company on a one-year contract, wanted eventually to have her own electronics store in Pontianak. She had no intention of applying for a PNS job. She feared that, if she was accepted, the government might send her back out to her hometown:

When I finish university, there is no way I will go back to my hometown. We are human...we want to develop ourselves all the time, we are looking for new experiences. I am not that interested in working as a PNS....Especially if 
I were assigned to a rural area, I would not be able to develop myself....We have to fit in if we are placed in a rural area.

Many other Chinese youths that I interviewed similarly stressed the importance of matching their future job with their educational background. Sometimes this might have been a cover for fear of failure, because they also assumed their chances of being accepted into the bureaucracy were minimal. Vanka (22), a Chinese woman who had come to Pontianak from a small village, told me: 'I heard that if you want to apply for a PNS, only natives (putera daerah) will be considered. Non-indigenous people (non-pribumi) like the Chinese will definitely be refused.'

The contrast between Chinese and non-Chinese youths' work aspirations became clear in a small survey I conducted (see Table 1, further discussed below).

My observations on what shapes youth work aspirations differ sharply from those of others. Arnett (2004) describes young people in the United States as eager to explore their work options before deciding. Exploring is

Table 1. Work aspiration by ethnicity.

\begin{tabular}{|c|c|c|c|c|c|}
\hline & & \multicolumn{3}{|c|}{ First choice } & \multirow[t]{2}{*}{ Total } \\
\hline & & PNS & Business & $\begin{array}{l}\text { Worker in } \\
\text { private } \\
\text { company }\end{array}$ & \\
\hline \multirow[t]{12}{*}{ Ethnicity } & Malay & 140 & 10 & 3 & 153 \\
\hline & & $91.5 \%$ & $6.5 \%$ & $2.0 \%$ & $100.0 \%$ \\
\hline & Dayak & 34 & 8 & 2 & 44 \\
\hline & & $77 \cdot 3 \%$ & $18.2 \%$ & $4.5 \%$ & $100.0 \%$ \\
\hline & Madurese & 19 & 1 & o & 20 \\
\hline & & $95.0 \%$ & $5.0 \%$ & $.0 \%$ & $100.0 \%$ \\
\hline & Javanese & 39 & 1 & o & 40 \\
\hline & & $97.5 \%$ & $2.5 \%$ & $.0 \%$ & $100.0 \%$ \\
\hline & Others & 21 & 3 & 3 & 27 \\
\hline & & $77.8 \%$ & $11.1 \%$ & $11.1 \%$ & $100.0 \%$ \\
\hline & Chinese & 2 & 30 & 13 & 45 \\
\hline & & $4.4 \%$ & $66.7 \%$ & $28.9 \%$ & $100.0 \%$ \\
\hline \multirow[t]{2}{*}{ Total } & & 255 & 53 & 21 & 329 \\
\hline & & $77.5 \%$ & $16.1 \%$ & $6.4 \%$ & $100.0 \%$ \\
\hline
\end{tabular}


part of constructing their personal identity. Pontianak youth, by contrast, all seem to know what job they want without having to explore options. Educated non-Chinese are sure they want to enter the bureaucracy; most Chinese want to start their own business or at least work in a dynamic, challenging private company. Unlike Arnett's industrial-city western youth, educated youth in this provincial town in a developing country are not free to follow their own inclinations. Not individual capacity but various structural factors shape their work opportunities. As I tried to unravel what these factors might be, I faced three puzzles.

The first puzzle is this fixation on finding perhaps the most boring job in town. I could not get over my amazement at the number of nonChinese youth in Pontianak - Malay, Dayak and Madurese - who wanted nothing more than to 'be a PNS'. Where was their need for self-actualization? Most PNS with whom I spoke did not find their job very interesting, and the image is that PNS actually do very little work. ${ }^{4}$ When I came to one of the local offices at ten o'clock in the morning, the woman taking care of my administrative necessities chatted amiably about her 'busy' schedule outside the office. When she was finished with me, she walked towards her desk and said with a smile of satisfaction that it was time for games on the office computer. Soon she would leave to pick up her daughter from school. This is what Pontianak's educated indigenous young people aspire to - a job in the bureaucracy, any job at all, regardless of their educational background. Even those of my informants who said they wished to become a teacher emphasized it had to be as PNS. If they had to choose between becoming a teacher in a private institution and becoming a PNS in the bureaucracy, they would choose the latter.

A second and related puzzle arose from Lia's anxious exclamation, 'See, it's a Dayak!' Entering the bureaucracy was apparently not a matter of acquiring the right qualifications, but of being born into the right ethnic group. In the minds of these young people, 'getting in' was a competition that ran along the lines of ethnic patronage. This bureaucracy was a long way from the advanced, dispassionate organization that Weber (1968:9561005) depicted. What kind of organization was it for Pontianak? To understand this would be to understand the source of the anxiety young Malay and Dayak graduate job seekers felt.

The third puzzle arises from the completely different aspirations, in the same town, among ethnic Chinese educated youth. They do not share the anxiety of ethnic competition in fulfilling their aspirations. Why is that so,

4 Berkat, 'Makan gaji butak,' 10 January 2009. 
and what does this tell us about the socialization process in an ethnically divided provincial town?

This chapter explores the process of growing up through the domain of work in an Indonesian provincial town. It focuses on university-educated youth in the provincial city of Pontianak. It begins by asking how nonChinese youth justify their PNS aspirations, and aims to understand how limited chances, unfair competition and ethnic prejudice shape their dreams and anxieties in their quest for upward mobility. It finds that family is particularly important to them. Work aspirations are less about identity construction than about securing a livelihood that enables young people to fulfil family obligations.

To help solve the three puzzles, I will first describe how Pontianak's labour market has historically been shaped by ethnic relations.

\section{Ethnic Work-Domains}

An Australian colleague who heard me present a paper at a conference could hardly believe that provincial youth still found the bureaucracy so fascinating. 'It seems such a 1980 os dream', she said. ${ }^{5}$ But it is true. A young Malay man on campus, when I explained early in my research that I wanted to know what kind of job young graduates in Pontianak were after, replied: 'Mbak, you don't need a year of research to answer that question! Everybody here knows that they all want to be a PNS.' The fierce competition to enter the civil service did not dampen his ambition. During the 2008 PNS recruitment in the new district of Kubu Raya, just outside Pontianak, for example, 8,083 applied for just 383 positions. ${ }^{6}$ If in the big cities industries and the private sector increasingly provide young people with opportunities for decent, secure and fulfilling work, in a provincial town such as Pontianak educated non-Chinese have much less choice. Industry is limited, and the Chinese dominate private business. A 'decent' office job (kerja kantoran) for them comes only from the state.

Pontianak, with a population of just over half a million in 2008 (Pontianak Statistics Bureau 2008), is located at the mouth of three rivers: the Kapuas, the Small Kapuas and the Landak. Its strategic location made trade the basis of its growth. The rivers remain an important transportation route to and from the interior. The province of West Kalimantan lies

5 Pam Nilan, at the conference 'Growing up in Indonesia: Experience and Diversity in Youth Transitions,' Conference, Canberra, Australia (29 to 31-10-2009).

6 Berkat, '6710 Pelamar rebutkan 383 lowongan,' 20 December 2008. 
in Borneo. Its four million inhabitants (Badan Pusat Statistik 2011) reside mostly near the coast. Agriculture, trade and the service sector make up most of the domestic product. The province is known for its fruit and expanding palm oil plantations. Rice production is limited when compared with Java (West Kalimantan Statistics Bureau 2010). In the past, logging drove the province's economy, but crackdowns on illegal logging bankrupted many major logging companies, increasing already high unemployment in the province. ${ }^{7}$

In Pontianak, most people work in the trade and the service sectors (the latter includes government); industry is not prominent. Numerous government offices extend from the west to the southern part of the city. The mayor's offices stand on the Kapuas river bank. The provincial government's offices are in the south, near the state university Tanjungpura and the Mega Mall. The new mall has become one of Pontianak's most visited entertainment centres. Pontianak's poor mostly live in the north, across the Kapuas River - mostly poor Chinese and Madurese working their market gardens. Several local, Chinese-owned rubber-drying sheds line the northern bank of the Kapuas, but they employ few workers. Some new national-level agribusiness companies have started hiring low-skilled female workers through job fairs facilitated by the local government. ${ }^{8}$ The educated young dominate the town's statistics for the un- and underemployed (Pontianak Statistics Bureau 2008).

Ethnicity has always been important in West Kalimantan's social landscape (Prasojo 2011:52). The province's slogan is 'Harmonis dalam etnis' (harmony in ethnic diversity). Four groups dominate provincial ethnic dynamics: the Malay (42\%), Dayak $(32 \%)$, Chinese $(12 \%)$ and Madurese $(5 \%)$. Other migrant groups include the Javanese, Bugis, Padang, Batak and Sundanese (Ridwan Rosdiawan, Hudi and Shaleh 2007:22). Transmigration programmes in the 1980 s ensured there are more Javanese here than Madurese, yet they are considered to integrate better than the Madurese and are not prominent in ethnic tensions (Alqadrie 1990:62; Ridwan Rosdiawan, Hudi and Shaleh 2007:23). In Pontianak, Chinese at about one third make up the largest group. They are followed by Malay (a quarter), and then the Bugis, Javanese, Madurese and others. Whereas Dayak are the majority in the province's interior, only a small number of Dayak live in Pontianak (Ridwan Rosdiawan, Hudi and Shaleh 2007:26).

7 Berkat, 'Pekerja Kayu Kembali Demo ke Kantor Bupati,' 6 December 2008.

8 Tribun Pontianak, 'Perusahaan Batam buka di Pontianak,' 18 October 2008. 
Apart from the Chinese, the other groups are predominantly Muslim, so that Islam is Pontianak's majority religion. ${ }^{9}$

Ethnic and familial networks shape employment patterns to an important degree in West Kalimantan (Van Klinken 2003:22-3). Malays dominate the civil service, but many Malays are also involved in farming and petty trade; Dayak are farmers, petty traders and also teachers; and Madurese work in informal sectors such as transport (pedicabs, small ferries, taxis) and petty trade (fruit, vegetables and street-side food). The Chinese are the dominant players in retail and wholesale trade and in services, often employing non-Chinese as workers. In urban Pontianak, many Malays also work in petty trade and small restaurants (warung makan). Only a few Dayak occupy middle-level civil service positions (Achwan et al. 2005).

Riwanto Tirtosudarmo (2002:4) writes that West Kalimantan's is a 'history of migration, or in other words, a history of interaction between migrants and the local people (or those who had arrived earlier) in this area'. The Dayak and Malay are considered the 'original' ethnic groups, while the Chinese and Madurese are migrants. Arab immigrants in the 1700 s established what would be known as 'Malay' sultanates, located on the coastal areas (Pemerintah Kota Pontianak 2009). The Kadariah sultanate in Pontianak was one of the more prominent ones. Dayak who embraced Islam were considered Malay; indeed, Muslims from other ethnic groups are also often considered Malay, with the exception of the Madurese. Some Dayak later moved to the interior (Adri 2007).

The Dutch arrived seven years after the establishment of the Kadariah Sultanate (Pemerintah Kota Pontianak 2009).The Christian mission penetrated the interior in the late nineteenth century, and most Dayak converted in the twentieth. Unlike the Dayak Muslims, Dayak Christians maintained their ethnic identity. They constructed an ethno-religious identity that paralleled Dayak culture with Christianity (Ridwan Rosdiawan, Hudi and Shaleh 2007:22-3). The Malay sultanates cooperated with the Dutch and provided access to resources (including land), but the sultans also got military protection from rivals (Van Goor 1986). The Dutch-Malay partnership gave Malays prestige. The Dutch used them to colonize the area through indirect rule (Siahaan 1974:32). The partnership further marginalized the Dayak, who had already been positioned as ulun, or slaves of the sultans (Tangkilisan 2005).

9 Sejarah Melayu: Kesultanan Kadariah. http://history.melayuonline.com/?a=bU5WL 29QTS9VenVwRnRCb20\% ${ }_{3} \mathrm{D}=$ (accessed 25 February 2008). 
The Chinese first came to the northern part of West Kalimantan early in the nineteenth century as farmers (Heidhuis 2003:27; Siahaan 1974:20). The discovery of gold encouraged more to come. To protect their economic interests, the Chinese established their own mutual-aid organizations, called kongsi, which facilitated the accumulation of capital and the reproduction of Chinese cultural practices. These strategic steps later facilitated Chinese domination in trade, though some remain farmers today (Siahaan 1974:23-5). Most Chinese are Buddhist or Confucian.

The Madurese, from the island of Madura off East Java, first came to West Kalimantan as low-skilled workers for the Malays, beginning in the early twentieth century (Hendro Suroyo Sudagung 2001:93). The flow increased in the 1920 s and $1930 \mathrm{~s}$ as the Dutch built new roads and towns (De Jonge and Nooteboom 2006:258). The Madurese are Muslims, but retain a separate identity from the Malays.

Ethnic stereotypes are rife. Malays are said to be Islamic, educated, urbanized and of higher social status than the Dayak, who are Christian and rural. Chinese are said to be exclusive and wealthy, while the Madurese are seen as poor, uneducated, violent and strongly attached to religious leaders from Madura. In reality not all Chinese are rich (Sikwan and Triastuti 2004). In recent years many Dayak Muslims are refusing the Malay identity and calling themselves Muslim Dayak (Alqadrie 2002:6).

These ethno-religious identities are intensely politicized and have led to a series of bloody ethnic conflicts. The conflicts of 1997, 1999 and 2001 pitted Dayak and Malay versus Madurese and occurred around the moment of decentralization (Davidson 2008; Wawa 2000; Prasojo 2011:51). All my informants' anxieties, and their hopes of upward social mobility in an era of changing ethnic relations, can be traced back to these episodes.

The ethnicized employment market in this provincial town leaves few options for educated non-Chinese young people besides the PNS job. How do the young people themselves justify their choice of work aspiration based on these perceived opportunities? I conducted 106 indepth interviews with university-educated youth, as well as a small survey among university students $(\mathrm{N}=369)$ to answer that question. Some of my in-depth interview respondents were drawn from the survey. The students were randomly chosen. I went to four universities and distributed the questionnaire in some of the classes. All students in the selected classes filled out the questionnaire. The research team made sure that the students answered all the questions, to minimize missing or ambiguous answers. The survey population proportions are: Malay $44 \%$, Dayak $14 \%$, 
Madurese $7 \%$, Chinese $15 \%$, Javanese $14 \%$ and others (including Bugis, Batak and Minang) $8 \%$. Of the respondents, $55 \%$ were male. The four universities were: Tanjungpura University, STAIN, STKIP and STMIK Widya Dharma. ${ }^{10}$ In Pontianak, even the universities are ethnically stereotyped. I chose mine for that reason: Tanjungpura University is associated with Malays, STAIN with Madurese, STKIP with Dayak and STMIK with Chinese.

\section{Puzzle 1: Why Become a PNS?}

Many non-Chinese youths of lower-middle-class backgrounds consider PNS a form of upward mobility. The bureaucracy is accessible to them, promises a stable income and status, and allows them to fulfil family obligations. The stability outweighs the size of the salary, which is often not very high. Low PNS salaries are a stock item in local media. One story in Berkat starts with two PNS at a warung kopi. Asked how he is doing, one says: 'You ask how I am doing? It's like you've just known me. Everyday we go to this warung kopi and you still ask how I'm doing? This is how life has always been for us PNS. I only have money on the first day of every month. Even that won't last long, cut to pay back loans.... The other replies, 'You and I share the same fate. My salary is also always cut. It gives me a headache...even if there is a rise, it won't solve our problems as a lowerechelon PNS'.11

In reality, however, 'side money' can exceed their salary. This includes gifts, often of dubious legality, from personal or corporate clients for support with government projects. The steady income also creates access to credit schemes, for example, to buy a motorcycle. Lian (27), a Malay young man, told me: 'You know how important a motorcycle is to get to places here. That is why people are competing to enter the PNS.' A mortgage on a house is also very popular; in fact, it is so popular that housing was excluded from a city regulation of March 2009 banning PNS credit

10 Tanjungpura is the main state university in the province. STAIN (Sekolah Tinggi Agama Islam Negeri) is a state higher-education institution that places Islamic teachings in its core curriculum. STKIP (Sekolah Tinggi Keguruan dan Ilmu Pendidikan) is a private higher-education institution, focusing on training future teachers, while STMIK (Sekolah Tinggi Management dan Informasi Komputer) is a private higher-education institution mainly teaching management and computer science.

${ }^{11}$ Berkat, 'Jangan nak berutang', 24 February 2009. 
applications requiring instalments of more than $40 \%$ of the monthly salary!12

The pension, while small, guarantees lifetime security in a country that is for most people not a welfare state. And it goes on giving - the pension of a deceased PNS goes to the surviving spouse. Tina (24), a Dayak young woman, is the daughter of a deceased police officer. She told me:

During good or bad times we still have money. If you're a businessman, you get millions of rupiah, but you don't know the future...if you're a PNS, even when you're retired, you have money for your children to eat. Even though my father has passed away, I still enjoy the benefits from his pension. I want that for my children, I want to become a PNS.

A pension is also a buffer against stigmatization in old age. A Madurese young woman, Wati (28), told me it would protect her from the shame of having to go into one of the free retirement homes subsidized by the Ministry of Social Affairs: 'If I cannot get a job in the civil service, then who will take care of me when I can no longer work? I would probably live in a retirement home (panti jompo). People would pity me. I don't want that.'

The stability, opportunity (side money and credit schemes) and security of the PNS job contrasts with the low, unstable income and uncertain future for those in the lower class in Pontianak working in the informal sector, such as small shops. Formal-sector alternatives for non-Chinese youth are usually low-end service jobs such as sales promotion or checkout girl at the mall, or waitress in a global restaurant chain. These jobs may bring a stable income, but the pay is low and the contracts uncertain. All this gives the PNS status, as Aas, a 26-year-old Malay young man, told me: 'The motivation to join the PNS is to acquire a good social position (kedudukan sosial).'

Many non-Chinese aspirant PNS emphasized the importance of societal recognition, especially within their own ethnic group. Wearing a PNS uniform is the public symbol of success. This was mentioned by Wawan (30), an unemployed Malay young man who graduated from the Faculty of Forestry in 2008.

I would say the bottom line is this...I prefer a job as a PNS. If I am a PNS, in the eyes of society, I will have status. If I am not a PNS, then I have less status, unless I am really successful at what I do. My family will also have status,

12 Berkat, 'Larang pegawai pinjaman uang: potongan gaji di atas 40 persen,' 31 March 2009 . 
because here, if one is successful, the family is also successful in society. And people notice that when one wears the uniform.

The uniform as status symbol is carefully guarded, as evidenced by a media debate on whether temporary civil servants (honor) should be permitted to wear it. ${ }^{13}$ The mayor recently decided the answer was 'no'. When I showed Nia (24), a Malay young woman, the mayor's new policy of limiting the uniform to permanent PNS, she agreed that honor were threatening to deflate its value:

I often meet my friend, riding her motorcycle, when I am on my way home. I have always thought it was all right. She is a temporary worker (honor), but she wears the brown uniform. Yes, really she wears a uniform. Maybe the policy is still new. That is why she is in the uniform, even though she is actually not allowed to wear the uniform yet.

We were having lunch at a small canteen in front of a government office. I asked her what was so important about the uniform. She replied: 'Look around, see those PNS in that corner? Many of the PNS come here to eat. We feel, I don't know (gimana gitu - indicating reluctance) when we see them. They are so confident, and proud in their uniform. They know everyone knows they are a PNS.' The uniform is a symbol of power. As access to it is further restricted, its value only rises.

Unlike the uniform, the free use of state motorcycles, cars and houses is only available to PNS of a certain position. Dino (21), a Malay man, told me this was the reason why he wanted one day to become head of a local office:

I want to be a kepala dinas (head of office). They have access to office cars, sometimes houses (rumah dinas). Everyone will know one's position if they stay in a rumah dinas. I think that is achievable. If a person obtains a bachelor's degree, he will be at level III (golongan III). It is easier to climb up the career ladder from there.

Whether through credit or as a state facility, a 'proper' house is the ultimate goal. Pontianak's peaty soil is unsuitable for anything but timber houses on stilts, but a proper house has brick walls and a tile floor, as in Java. The added expense of deep foundations is part of the prestige. A car comes a close second. Lanny (24), a Dayak young woman, says:

For us, success is...success is about achievement, like from the material domain...a house, having a car, or a new car. People will judge us, people are considered a success if they can obtain a house and a car. Usually it is those

13 Berkat, 'Pemkot tertibkan pegawai “titipan”, 27 March 2009. 
in the civil service who are able to afford a house and a car. I don't know what kind of effort is put in to obtain the money to buy those goods, I don't know. But that is how people see success, from large observable material wealth. With a car, you can also show your success in public more than with a house.

A more intimate form of symbolic power is the opportunity to fulfil social obligations to the family. This is often viewed as the key to achieving 'adult' status. A regular income allows the dutiful child to assume the responsibility of assisting their parents. In the West, responsibility is often thought of as referring to oneself (Arnett 1998). But in Pontianak, as in district towns in India (Seiter 2009), youths do not see responsibility as limited to oneself. Adulthood is achieved when one is able to extend responsibility towards others - especially to parents and the wider family.

Financial responsibility can also enhance their bargaining power in the family. Hendar (22), a Malay man, explains:

I need a job to earn money, to help the family and for myself...but more importantly for my family, that is more important....That is why I want a PNS job. Recognition from my parents, my older brother - but especially from parents - is important...I have more say in decision making in the family if I can support the family each month.

Most of the youths I interviewed are from lower-middle-class families. Their parents are usually teachers, low-ranking bureaucrats or owners of small businesses. A minority are from lower-class families whose parents work as farmers, plantation workers or workers in small businesses. These youths usually will not inherit a house. Credit schemes for housing allow them to become independent adults. The non-Chinese young people I met in Pontianak took an amazingly long-term view of their family responsibilities. Only when they have their PNS status and can see that their future family is safe will they feel confident enough to 'move on' and think about marriage. Owning a house, after marriage, is the start of a new mode of relating to parents. Agus (24), a young Malay man, explained:

If married people still live with their parents it does not mean that they are less of an adult than those who live independently....Maybe they need a temporary place (numpang dulu), because people start a new life from zero....But a PNS can have a house through credit. They don't have to wait too long to save money for a house. The PNS can become independent sooner.

A house facilitates independent decision-making and lessens the parents' burden. Mimi (25), a young Dayak woman, said: 
If we are away from our parents, we become an adult faster. Because when we are with our parents, every time it is 'emak-emak (mom, mom), pak, pak (dad, dad), mak, I can't do this, I can't do that.' When we're alone, like when we have our own place, we have to try to solve our own problems.

Clearly class origins tell us a lot more than merely not inheriting a house. They tell us something about values, such as the commitment to family. It also shapes attitudes towards the future, including the anxiety about secure incomes and perhaps, too, the lack of imagination about a world beyond their own family circle. These values come from their parents. Borjas (1992) used the term 'ethnic capital' to show the importance of parental inputs and ethnic environment in youth chances for upward mobility. Work aspirations are formed through values that run through the family in certain ethnic subcultures. And of course the opportunities are structured ethnically. Non-Chinese parents are especially likely to idealize the PNS job if they themselves experienced insecurity. Bu El is a 50-year-old Malay mother of four. Her eldest daughter has just graduated from university and is looking for work. She has two other children still at university. She says: 'I imagine my children when they have finished university. If she is a PNS, it is a full success (sukses penuh).' Her father had a job as a low-skilled worker with a private company with decent pay. But when she was in junior high, he was fired and the family's finances collapsed. The fall from prosperity to poverty was traumatizing. She says: 'That is why I expect my children to become a PNS.'

Even though a pension does not directly involve parents' self interest, it is very much part of the parental plan for their children. I met a 65-yearold Malay man, Pak Alip, a retired PNS teacher with three grown children - all PNS. When Pak Alip heard that during my fieldwork I was teaching at a private university in Pontianak, he asked, 'Then you are not a PNS? Then you don't get a pension, right?' I agreed, and asked him why pension was so important to him. He replied, 'I have two daughters in the PNS, and my son is also in the PNS. I am a lucky man, I know that my grandchildren will be secure. That is why pension is important.'

The uniform of one member in the family is a sign that the whole family has 'connections'. Arjan, a 30 year-old Madurese man, said:

If we wear a uniform, the whole family will be proud. Other people will know that someone in the family is a PNS...they know that we can perhaps help in this and that, like giving information and stuff. Just as I was offered to enter the PNS by another PNS. People know that a PNS can do all that.

Even a low-ranking PNS has the power to negotiate placement in the PNS recruitment process, provided they have a good relationship with a 
higher-ranked bureaucrat. People who offer this service are known as calo (middle man). During my fieldwork, the newly formed district of Kubu Raya started a PNS recruitment process. The number of calo produced a storm of bribery allegations. First, there was the wife of a district parliamentarian and her sister. They recruited a go-between who then searched for interested applicants. The go-between set up the connection, for which the two sisters would give him a small amount of money (Rp 100,000-200,000). After that, this go-between would carry the applicants' much higher fees to the two sisters. The amount depended on the salary a successful applicant could expect to earn. A high-school graduate pays at least Rp 40 million (US\$ 4,00o) to enter the police force. 'The go-between admitted to the police that he had given a total of $\mathrm{Rp} 75^{\circ}$ million to the two sisters.' ${ }^{14}$ The police got busy, more calo were arrested, and that particular recruitment process was annulled in its entirety. Since then people have become more cautious, but no one believes these practices have disappeared. Bu Idah is a PNS, teaching elementary school. Her husband wants to save up a special fund for when their son finishes university. Through her friends she has acquired a map of middle men they can approach.

The downside to this system of connections is that it excludes many who might otherwise be well qualified to enter the public service. Dea (25), a Dayak woman whose father is a teacher, says hesitatingly:

I didn't think of the PNS as my work aspiration, well not that much. But I wouldn't refuse if I were accepted, I would be happy. My parents say that they can seek help from my father's friend. But his friend's position is not strong. The position will probably go to someone else with a stronger connection.

Bernadus, a young Dayak man whose parents are farmers, wrote 'starting my own business' as his first work aspiration choice in my questionnaire. But when I interviewed him, he told me he actually wanted to enter the police force, but had not been accepted. He did not tell me how good his school results were, but he himself blamed a lack of connections, a result of his parents' occupation:

Most of my friends get into the police force using money. I hate that, I hate those kinds of policemen....But I really, really want to be a policeman... when I applied after high school, I did not use any connections (orang dalam). Connections...who? I don't have any. Even if I had one, I would need

14 Berkat, 'Penipuan calo CPNS', 17 November 2008. 
to prepare a lot of money, mbak. 40 million, 50 million, 60 million rupiah. Do you think I am capable of providing that kind of money?

This also shows that an even higher percentage of young people, especially those from the lower class, may aspire to the PNS job than stated in the result of my small survey.

\section{Puzzle 2: Why the Fear? Ethnic Bosses and the Bureaucracy}

The handover of various powers from the central to the local government has triggered many local power struggles. In some areas local ethnicity has become an important condition for attaining certain powerful positions, in order to counter a perceived history of Javanese domination. The Malay and the Dayak in West Kalimantan are considered 'sons of the soil' (putera daerah) with special rights. But putera daerah are not united. Pemekaran, the establishment of new districts by sub-dividing old districts, is an opportunity to 'officially' claim ethnic territories. The power struggle is mainly about civil-service positions. Combined with a strong patronage system and the manipulation of rules by ethnic elites, the competition has significantly strengthened primordial ties. ${ }^{15}$ As West Kalimantan continues to urbanize by migration from the countryside, despite a weak labour market, non-Chinese young people find themselves in a highly ethnicized competition for bureaucratic jobs. During a graduation ceremony at the Widya Dharma University, I sat next to a proud Dayak mother. She told me that the current governor, Cornelis, a Dayak, had made Dayak needs his priority. New roads into the interior had made it easier for young Dayak to come to the city for their education. She felt Cornelis was reversing the historic marginalization of the interior that had been the Dayak fate since colonial times (Peluso and Harwell 2001:84; Peluso 2009:50; Davidson, 2003:9; Eilenberg and Wadley 2009:61-2; Van Klinken 2008:37; Bamba 2004:70). Oren (23), a Dayak young man studying in a university in Pontianak, told me:

The governor is now Dayak, the head of district in the interior happens to be Dayak, so there is a kind of policy to recruit Dayak people with potential, those who found it difficult to get into the civil service in the past now easily get in.... There still needs to be more effort to bring them in. Even if they are a bit unfit, efforts should be made to get them certain positions that fit their capabilities....Why not? Why is it like that nowadays? Because before it was very difficult.

15 Berkat, 'Penerimaan CPNS jangan sampai ada titipan', 18 December 2008. 
Dayak optimism about seizing access to bureaucratic jobs through pemekaran is producing anxiety among Malays like Lia. Some hope against hope that the bureaucracy is not a finite resource. Artha (25), a young Malay man, says: "There is no change (in how Malays think of their chances of getting into the PNS). It is still like before, even though we know that there is more Dayak power.' This might be true at city or district level, but unfortunately jobs at the provincial level are a zero-sum game. Madurese share the growing Malay pessimism about their chances of getting into the PNS. For them, though, the issue is even more discouraging. Their general lack of education has left them with insufficient social networks in the bureaucracy. Even having a Madurese as deputy mayor of Pontianak will be of little help. Aziz (24), a Madurese young man, says: 'There are only around five Madurese who have a master's degree, and now a deputy mayor. But I am not sure he will be able to help that much. Not because he doesn't want to - the Madurese are just not strong enough.' Aziz's pessimism about his chances did not prevent him from believing that a PNS job is the only ticket to upward mobility. His statement reflects Pontianak's common discourse on ethnic jobism in the local bureaucracy, as expressed by Lia in the opening quote. The more elites of a particular ethnic group hold important positions, the stronger they are in providing access to people of their own ethnic circle to jobs in the bureaucracy.

To make things more complicated for educated young Malay men expecting to follow in the bureaucratic footsteps of their fathers, more and more women are now entering the PNS workforce. My small survey indicates there is no gender difference in work aspirations among nonChinese young people in Pontianak. Both men and women aspire to becoming a PNS. A local newspaper carried a Malay op-ed about this as follows:

It cannot be denied that being a civil servant is one of the most desired jobs. Society thinks that a person is not successful before he/she becomes a civil servant. Unemployment is associated with men....Many jobs men are entitled to have been taken away by women, because intellectually, women are better performers. In terms of honesty, neatness and conformity, women outperform men....It would be logical and just to have an 80:20 proportion in the recruitment of civil servant jobs ( 80 for men, 20 for women). ${ }^{16}$

The Malay young man who wrote this piece recognized women's superiority in work performance (not without some stereotypes), yet his call for

16 Pontianak Post, 'PNS laki-laki lebih prioritas', 10 January 2008. 
affirmative action on behalf of men illustrates how highly Malay young men value the PNS job. In 2007, 60\% of PNS positions in the Pontianak Government office were held by women (Pontianak Statistics Bureau 2008). This contradicts non-Chinese society's expectation that men are the breadwinner in the family, and also underlines once more the scarcity of breadwinning opportunities through the state. While some Malay young men feel threatened by this form of women's emancipation, young women, not surprisingly, see it as an opportunity to increase their bargaining position vis-à-vis men. This includes increased autonomy in choosing their future spouse, as seen in the case below.

Tiwi (24) is a Malay young woman who just graduated from a university in Java. She had a boyfriend whom she had been seeing for five years. Her boyfriend was still struggling to finish his undergraduate thesis. This would not have become a problem were it not for the fact that Tiwi was accepted as a PNS in up-country Sintang in January 2009. Then everything changed. 'Why do I feel sick (ill-feel) of my boyfriend?' Tiwi asked me rhetorically one day when she visited my 'office'. The appointment forced her to rethink her relationship with her boyfriend. She felt she now had a good and stable job, while her boyfriend was going nowhere (ndak kemane mane). Later on, she did break up with her boyfriend, and formed a new relationship with another young man.

The aspirations of the non-Chinese educated young people in Pontianak might be representative of a lower-middle class that dominates the bureaucratic politics of the city. Many of the youth in the small survey (30\%, all non-Chinese) have at least one PNS parent, mostly lowerechelon bureaucrats or teachers. This fits the lower-middle- class picture of the Indonesian provincial town also described by Evers and Gerke (1994). Unlike the middle-class youth in developing countries described by Arnett in his further writing (2005:28-9), who enjoy a long transition to adulthood accompanied by identity exploration, these lower-middleclass Pontianak youth do not explore their options. They are more like the youth in China described by Nelson and Chen (2007:87-8), who also have very limited opportunities to explore work options, due to a lack of educational opportunities and a declining labour market.

\section{Puzzle 3: Chinese are Different: Socialization into an Ethnic Subculture}

The dynamics of ethnicity, gender and class that structure young people's work aspirations come to them through their families. Both non-Chinese and Chinese youth told me that pleasing their parents was important 
when making their choices. The non-Chinese youths seemed to be less autonomous than the Chinese in this regard. When friction occurs between parents' wishes and children's plans, Chinese youth express more freedom to take their own path. For instance, Hutomo (25) is a Chinese young man from the northern district of Singkawang who is now a PNS. He was the only Chinese PNS I met during my research. His parents were not pleased with his decision to enter the PNS, but they gave him enough freedom to make his own decision and face its consequences.

My parents wanted me to have my own business. But it is impossible for parents to force their wishes upon their children. I will take any job offer that comes. My parents told me whatever I choose, just go along with it. Actually, it is based on self-awareness that I chose this path, and I will face the consequences. Since I was little, my parents told us things like that. Like if we want to open a business, if we become bankrupt, that that is our own responsibility. My parents really emphasized that.

Hutomo admitted that being a PNS had not been his dream. It was just one of several work options. Before entering the PNS, Hutomo worked in a private company for four years. However, he did not earn enough money to save. So he quit, and started applying for other work. Out of all the work applications he sent, this one passed. He was not overwhelmed with his acceptance in the PNS, but he was thankful that his current income of Rp $1,400,000$ was enough to save some money. Being a Chinese PNS was also something he was proud of, because he made it there on his own. He compared the experience favourably to his previous acceptance in private companies, where he had to rely on his Chinese networks.

On the other hand, most non-Chinese youth tend to submit to their parents' expectations. Those that do not, seem to feel guilty. Kaka (34) is a Malay young man working as an NGO activist, involved in community development. He felt he was living his dream, because he had always wanted to work with the local community. But he still feels guilty for not fulfilling his parents' expectations of joining the PNS.

When I started university, I was the only one in the family to go to university and escape life in the harbour. My father said that I had to become a PNS. There was conflict between us. Even though I like my NGO work, until now I still regret that I did not enter the PNS. I really regret not following what my deceased father expected of me. I was unable to make him happy.

This shows that work aspirations are not always related to self-fulfilment in the Arnett sense of developing one's personal identity. Self-fulfilment for these lower-middle-class non-Chinese youth is about forming work aspirations that are in line with their parents' wishes. 
Siahaan (1974:41-3) shows that the ethnic Chinese population in West Kalimantan increased markedly over the 65 years between 1905 and 1970. Until the 1970s, most Chinese in West Kalimantan formally remained foreign citizens. The New Order's anti-Chinese discrimination resulted in costly naturalization processes that poor Chinese could not afford. This forced them to find ways to survive outside the state's domain. Recently, the reform era has opened more space for the Chinese to fully practise their citizenship, including suffrage, ${ }^{17}$ and improved access to state tertiary-education institutions, while still retaining their religious beliefs. There is also more space for the Chinese to reach political positions and become state elites. For instance, the deputy governor of West Kalimantan is an ethnic Chinese. All these changes affect young Chinese people's beliefs in the opportunity to enter the bureaucracy. However, parental expectations and memories of New Order anti-Chinese discrimination are strong. One common justification for preferring to work outside the state domain is the 'self-generating pension scheme' in the private sector. Trade produces higher savings than the paltry PNS pension schemes. Many Chinese own a ruko in the centre of the city, along Gadjah Mada and Tanjungpura streets, selling foodstuffs, electronics or Chinese herbal medicine. Chinese traders also sell essential foodstuffs, fruit and traditional cakes in traditional markets. The Chinese dominate the foodstuffs trade. Effective distribution chains and a strong capital base allows the Chinese to sell at lower prices. They also dominate service sectors such as hotels, restaurants and travel agencies. Small businesses usually hire Chinese helpers, while larger ones recruit both Chinese and non-Chinese workers. Dylna (19), a young Chinese woman, explained:

Chinese parents are proud of trade. Very few will wish for their children to become a PNS. PNS retire at 55, but in trade, no matter how old you are, you can always run your business. PNS salaries are also too low. If you are a PNS you only get a salary of 1 million rupiah. It is better to trade, because when we are old, we never know what illness we will have. And with only 1 million, what will we eat?

Unlike the non-Chinese youth who do not prioritize matching educational background and work when applying for the PNS, Ipin (20), a Chinese young man who is currently studying information technology at university, states that a match between educational background and work is a must if he were to apply for a PNS job.

\footnotetext{
17 Berkat, 'SBY ajak Tionghwa gunakan hak politik', 2 February 2009.
} 
If there is an opening for a PNS position that is in accordance with my major, I will then apply to become a PNS. But my intention of becoming a PNS is only $20 \%$. The rest $(80 \%)$, I want to have my own business or work in a private company, but only if I can have a high position.

\section{Conclusion}

Developmental psychologists have proposed that identity exploration in work is an essential stage towards constructing a healthy identity (Manning 2002; Arnett 2004). However, this offers a limited explanation for understanding young people's work aspirations in a Third World provincial town setting. This chapter highlights the experience of educated young people's transition to work in a provincial town in a developing country. Work aspirations in the process of education-to-work transitions are framed by structural opportunities rather than by individual choice.

The influential role of external structure in young people's work aspirations is not a monopoly of young people in provincial towns. In many rural and bigger cities of developing countries, class and ethnicity are often equally influential in shaping young people's work opportunities and aspirations (Seiter 2009:58; Arnett 2005:28; Jeffrey, Jeffery and Jeffery 2008). However, in provincial towns such as Pontianak, the influence of ethnicity among the lower-middle-class youth seems to be strong in shaping their work aspirations. Class is (among others) indicated by the occupation of the youngsters' parents. Most parents of the non-Chinese youth in my sample are teachers and lower-level civil servants, who see their chances of social mobility exclusively through accessing the civil service. In constructing their work aspirations, they prioritize how work will help them meet family obligations rather than individual ambitions.

There are historical and political reasons for the popular view that social mobility is only possible through the state. Ethnic mobilization, combined with systems of bribery and connections, have created new opportunities for non-Chinese youth in various categories to enter the bureaucracy. At the same, this system of ethnic patronage has created new obstacles for those without access to these resources. The resulting competition has created anxieties for educated young people, because alternative work domains, such as industry, are very limited. Feminization of the work force in the state domain creates further anxieties among young men.

On the other hand, the Chinese middle-class youth are similar to Arnett's emerging adults, who grow up through individual exploration 
and who focus on self-development. Mostly confined to the trade sector, values of initiative and self-deployment are much more prevalent among these youth. In general they are also from wealthier families, thus having more options in their life. The almost completely separate socialization of youth within the same town of Pontianak, down to different clothing styles and language, is one of the significant discoveries of this chapter. 